\title{
The Discipline of Judges in Accordance with the Jordanian Law (An Analytical Study)
}

\author{
Ahmad Fahd Mohammad Albtoosh \\ Assistant Professor \\ Ajloun National University \\ Jordan
}

\begin{abstract}
Discipline of Judges is one of the most significant issues that should be addressed when discussing the area of the Judicial Authority, because of its connection with the principle of the independence of judiciary. Judges are subject to the supervision and control of the Judicial Council, which is an independent authority, where the Council is the only authority competent to supervise all judges' affairs. The Judicial Council shall form the Disciplinary Board to discipline the judges. This board shall consist of at least three of the oldest judges of the Court of Cassation. The judge may appeal the decisions of the Disciplinary Board before the administrative court. The Jordanian legislations have tried to maintain the judge's independence in terms of providing all the necessary guarantees, while drawing the attention of the legislator and the Judicial Council to find special texts for the mechanism of challenging judges' disciplinary decisions and not leaving them to the general rules.
\end{abstract}

Keywords: Discipline of Judges, Jordanian Legislation, Judiciary, Judicial Council, independence of Judiciary.

\section{Introduction:}

All countries are subject to the rules of law and its will. Jordan as well as its three authorities: executive, legislative and judicial authority are also subject to the rule of law, and one of the most prominence principles which these authorities are based on is the principle of separation of powers. Article (27) of the Jordanian constitution stipulates that "The Judicial Power is independent," Under this article, the Constitution guarantees the judiciary independence, since it is of great importance to the role exercised by this authority, as the custodian of the application of the law and its implementation to all individuals and authorities in the State.

This principle grants the judiciary the right to prevent the other authorities and bodies from interfering in its work. Accordingly, the judiciary can maintain its interests and increase the confidence of the citizens of its reliability as it is the crucial guarantee of the rights and freedoms of individuals.Considering that, the judge is the most important element of the judiciary, he must enjoy the same independence that the judiciary has. Article (97) of the Jordanian Constitution stated that "Judges are independent, in the exercise of their judicial functions they are subject to no authority other than that of the law". Which ensured the independence of the judiciary?

One of the most core guarantees given to the judge under this independence is that the judge is unaccountable for the judgments he makes, no matter how wrong he is and whether this is a criminal, civil or disciplinary error.

Therefore, no authority or administrative body in the state can hold the judge accountable for his actions. This does not imply that they are not accountable or subject to law. But Judge's accountability is based on a mechanism that aims at sustaining his independence and impartiality. Therefore, the idea of the study focuses on the mechanism of discipline and accountability of judges while maintaining their independence.

\subsection{Significance of the Study:}

The significance of the study lies on the fact that judges are considered the most important elements of the judicial bodies, their decisions must remain away from being influenced by personal feelings and their work must not be subject to the interference of any other bodies. Therefore, the legislations grant him the immunity, which protects and enables him to exercise his duties fairly. These guarantees also applied if the judge is held accountable during the judicial inspection, and even in the case of referral to the disciplinary council and after the decision was issued against him.

\subsection{Problems Statement:}

- The problem of the study lies on how to establish an inspection and disciplinary system, which judges are subject to, without affecting the independence of the judiciary. 
- Specifying the appropriateness and adequacy of the guarantees surrounding the judge when he is subject to the judicial inspection and the disciplinary council, in a manner that preserves the neutrality and independence of the judge.

- Has Jordan succeeded in balancing the independence of the judiciary and its accountability?

\subsection{Research Questions:}

- What is the relationship between the judge's discipline and his independence?

- What are the rules of disciplining the judge?

- What are the disciplinary guarantees for the judge?

- Has Jordan succeeded in establishing legal controls to ensure that judges are disciplined to achieve a balance between their independence and their obligation to work?

\subsection{Research Methodology:}

The methodologies that followed in this study:

\subsubsection{The descriptive approach:}

The researcher used the descriptive approach to describe the legal texts, regulations and instructions that regulate the judicial work in Jordan, and to examine the subject of the study to achieve its objectives, reviewing jurisprudential opinions and judicial decisions related to the subject of the study.

1.4.2 Analytical approach: Through the reviewing the legal texts, regulations, instructions, jurisprudential opinions and judicial judgments related to the study and analyzing them. Other legislation which were necessary for the objectives of the study will be indicated.

\subsection{Limitations of the study:}

1 .The Judicial Independence Law. Act No. (29) of 2014

2 .Amended Law of the Independence of the Judiciary Law No. (26) of 2017 "reads with Law No. 29 of 2014"

3 .System of Inspection of the Regular Courts No. (100) for the year 2017.

4 .Instructions for inspection of the regular courts.

5 .Instructions for grievance of judges, which undermines their independence.

6. Code of Judicial Conduct for the year 2017.

\subsection{Previous studies:}

- Al-Qaisi, N, T (2017) Impact of Disciplinary Guarantees for Judges in Promoting the Principle of Judicial Independence (Comparative Study), Shari'a and Law Studies, University of Jordan, Vol. 44.

My study corresponds to the study of Al Qaisi (2017) in terms of the subject it deals with, which is the administrative subsidiarity of judges and guarantees of judges' discipline. Whereas, it differs in terms of that the study of the researcher was a comparative study between the Jordanian, Egyptian and Iraqi law, while my study was limited to Jordanian law, in addition that, the study of the researcher focused on identifying the competent authorities for each stage of judges discipline stages until the issuance of the decision. While my studies focused on a comprehensive demand for the control of the administrative judiciary on the decisions of discipline of judges.

Abu Saud, I, I (2016) Judicial Control of Disciplinary Sanctions in the Palestinian Civil Service Law No. 4 of 1988 and its Amendments, Master Thesis, Faculty of Sharia and Law, Islamic University, Gaza, 2016

Both studies dealt with the supervision of the administrative judiciary on the disciplinary decisions, through the statement of elements of the administrative decision, the cases of the absence of this element and the impact of this absence on the decisions. My study differed from that of the researcher that the researcher has dealt extensively with the nature of the disciplinary sanctions and the limits of judicial control and the reasons for the abolition of disciplinary sanctions; in addition to that the researcher study was related to the public employee, while my studies were about the judges. The researcher has dealt with the subject of the disciplinary decision's controls in the Palestinian law while my study was in the light of Jordanian law.

\subsection{Study Terminology:}

- A judge: is the jural person especially qualified to assume responsibility for settling the disputes and direct the deterrent punishment through practicing his constitutionals power in implementing provisions of the law in the lawsuits heard before him in order to establish the justice and maintain the rights. The power of appointing the judges shall be attributed to the Jordanian Judicial Council, which represents the top of the judicial authority pyramid and judicial authority within the Kingdom according to provisions of Law of Judicial Independence 
${ }^{1}$.Judicial Inspection: The process of collecting data and information that leads to knowledge of the efficiency of the inspected judge, in exercising his duties and the extent of his concern for the good performance ${ }^{2}$.

\section{- Administrative subsidiarity:}

The process of supervising and monitoring the judicial system, following up its members, guiding them, researching and investigating the causes of default within the judiciary, in order to remedy imbalances, deficiencies, negligence and manipulation, and to avoid their occurrence ${ }^{3}$.

\section{- Disciplinary Trial:}

It is the authority that performs the task of disciplining the judges, so that this authority alone is solely assigned to carry out that task without reference to another party ${ }^{4}$.

2. Judicial Inspection: Setting laws and regulations to safeguard the independence of a judge and prevent others from interfering in his job is not enough by itself, because a judge must also be abided by all the duties dictated by his job. Thus, it is necessary to monitor the performance of judges. Therefore, Judicial Council has sought to establish a special system for the inspection of judges to ensure that they fulfill their duties properly.

The Judicial Inspection System was issued for the regular courts No. (43) for the year 2015, which was cancelled, a new system was issued with the number (100) for the year (2017). The new system was issued under the provisions of Article (40) of the Judicial Independence Law No. (29) of 2014, which states in paragraph (A) that the Judicial Inspection Unit is subsidiary to the Judiciary Council.

The Judicial Independence Law, in article (40) paragraph (d), provides for the issuance of a special system to define the functions and powers of the judicial inspectorate and its work procedures 5 .

\subsection{Definition of judicial inspection}

\subsubsection{Constitutive definition:}

Inspection is a search and investigation. Actually, it does not differ from the concept of inspection in the constructive definition where it also means to search for what has been hidden.

The concept of inspection in legal terms is a procedure of investigation for the purpose of searching for crime-related objects that can be used to uncover the truth including persons, objects, homes and places. ${ }^{6}$

\subsubsection{Judicial inspection:}

Is to inspect Judicial performance and any other work carried out by the judge to identify his legal competency, his ability to perform properly, his discipline in conduct and his regularity in the work. The purpose of the judicial inspection is to clarify the errors in order to prevent them from occurring in the future and to be used for defining the professional competences of the judge for the purpose of promotion?

Judicial Council is composed of member judges who are appointed by a decision of the Judicial Council, a Senior inspector and a group of inspectors whose degree is not less than the second and the term of the membership is not more than four years non-renewable. The law provided that an inspector's degree must be higher than the judge who is to be inspected. The condition that membership in the inspection council is non-renewable increases the confidence of the judge during the inspection, so that he is confident that personal desires are not included in the evaluation process, or that there is enmity with a member of the inspection body. The condition of having a higher degree than the judges assures that the members in this position are competent, knowledgeable and wise. The judicial inspectorate shall perform the functions assigned to it by virtue of a system. These tasks are to inspect the judges, except for the senior grade holders, to prepare their annual reports, to evaluate the work of the judges in terms of the good conduct of the cases before him and the speed of dismissal.

The judicial inspectorate shall also determine the annual dismissal rate of the judge, inspect the work of the regular courts at least once a year and investigate the complaints referred by the President of the Judicial Council of the Inspection Body ${ }^{8}$.

\footnotetext{
1 Legal Terms, Ministry of Justice, mom.gov.jo, date of visit 11/4/2019

2 Makhlouf, A, S (2013, P.380) Waseet in explaining the new judicial organization in Saudi Arabia, Institute of Public Administration.

3 Al-Qaisi, N, T (2017) The effect of the general disciplinary guarantees of judges in promoting the principle of judicial independence, studies, law and regulations, University of Jordan, Vol.44., University of Jordan, Vol. 44, 2017, pp. 274-275. 
However, the exception for the senior grade holders from the inspection process, is not justified and may raise the question around the reliability of this action, because even the senior grade holder may make mistakes and need to be held accountable as any other employees. In terms of the mechanism of the inspection procedures, under Article (13) of the system of inspection of the regular courts, instructions were issued to determine these procedures. The decision to determine the judge's competence was not left to the absolute inspection authority, but procedures were identified for preparing the annual reports.

That the inspector examines at least fifteen different cases, which the judge scrutinized during the year or a year before, with giving the judge the right to choose two cases in which he has issued a distinguished judgement and scrutinized to be among the 15 cases covered by inspection. The information of the inspected cases is written in special forms which are filled out by the inspector or by the public prosecutor. And what is stated in the judge's file considered secret. It also considered the basis for assessing the judge's efficiency ${ }^{9}$. The Judicial Council did well (as he was the author of this law, regulations and instructions) when he established the basis for evaluating the competency of a judge and not leaving the mechanism for competency determination to the inspection bodies. In addition, the legislator also granted the judge the right to choose two cases in which he found that he had made a distinctive decision that was considered when assisting the judge.

\subsection{The subordination of the judge to the Disciplinary Council.}

According to Judicial Independence Law, the judge subordinates the Judiciary Council in their administrative matters. This Council represents the judiciary's highest administrative body and has the legal authority to oversee the affairs of all judges in the country on matters related to employment, discipline, accountability, transportation and dismissing, away from the interference of other bodies ${ }^{10}$.

Article (26) in paragraphs (a) and (b) stipulated that The Chairman has the right to administrative supervision on all judges; the Chief of the Public Prosecution have the right to administrative supervision on all Public Prosecution members ${ }^{11}$.Judges are subordinate to the Judicial Council, ${ }^{12}$ with no role of the executive power or even of the Minister of Justice in regulating any matter of judges, as this is incompatible with the principle of the independence of judges. Judge's subordination to the Judicial Council is merely an administrative implication, the sole purpose of which is to regulate and control the work of the judicial body and not to intervene in the judge's decisions, because there no authority on judges other than the law.

However, in the event that the judge commits offenses, he is not held accountable before the regular judiciary like any ordinary member of society. The purpose is not to protect the judge personally, but to preserve the prestige of the judicial body itself. The judge, therefore, is investigated before the disciplinary council which is formed by a decision of the Judicial Council. Article (30) paragraph (a) stipulated that the disciplinary council was to be formed from three judges of the Court of Cassation at least who are assigned by the Council and from other than its members for a period of two years. The Council has the right to assign more than one disciplinary commission. This Council shall be subordinate to the Administrative Council of the Judiciary Council. There shall be no interference in this Committee or in its decisions, but the role of the Council shall only be to regulate the affairs of this Committee administratively. These committees are not exploited to influence the judge's decisions by not punishing him despite committing the offense or exposing him to punishment without committing any offense.

3. Legal Regulations for the Discipline of Judges. The Judicial Council has granted the responsibility of the discipline of judges to itself by establishing a committee within the Council to discipline the judges in the event of committing violations or I case of filing a complaint against the judge. The members of this Committee are from the community of judges themselves. The council also sets several conditions for appointing members of the disciplinary committee. All these procedures aim at insuring the independence of the judiciary.

\subsection{Violations and disciplinary sanctions}

Article (36) of the Judicial Independence Law states in paragraph (a) that "Any violation to the duties of the position or any action do harm to honor, dignity or decency constitutes a blunder that the judge would be disciplined for."

To define the duties of the judge clearly, article (43) of the Judicial Independence Act, stated the Code of Judicial Conduct. Therefore, the obligations that the judge adheres to are mentioned in the judiciary independence Law and in more comprehensive ways than in the Code of Judicial Conduct, these texts identify the violations that may be committed by the judge. These violations include the following.

\footnotetext{
9 Instructions for the inspection of the regular courts for the year 2018, site of the Jordanian Judicial Council, date of visit 11/4/2019.

10 Al-Qaisi, op. Cit., P277

11 Judiciary Independence Law No. 29 of 2014, Official Gazette No. 5308, page 6001, dated 16/10/2014.

12 Nazir al-Qaisi, op. Cit., P. 277.
} 


\subsubsection{Violations related to the duties of the judge in his job}

Paragraph(2) of Article (36) of Judiciary Independence law states that "The violation to the duties of the position include delay of delivering a judgment, not to put a specific date for making comprehend the sentence, discrimination between the litigants, disclosure of the deliberations secrets, unjustified non-attendance, and inobservance of office hours"13.

The confidentiality of the deliberation is important so that the judge's judgment remains far from influencing him, but this secrecy in the deliberation does not prevent the hearings from being public. In accord to the Code of Judicial Conduct, the judge shall not interfere with the judicial functions of his colleagues in any way in their proceedings. The judge shall not hear any of the litigants or their agents in the absence of the other party outside the court proceedings, and he shall observe the standards of fair trials, justice and shall maintain public hearing, to abide by the provisions of the law at all stages of the proceedings until the verdict is issued, to avoid postponing of hearings for unjustified reasons, and to respect community diversity.

In the event that a judicial colleague dominates or influences a case that is before a judge, or in the event that a judge is subject to domination or influence, the judge shall inform the Head of the Judicial Council. In addition, the judge must respect the prestige of the court and abide by the rules of deliberation. As it is prohibited for him to disclose the secret of the deliberations before and after the verdict. Moreover, the judge must restrict his relationship with lawyers or others who are practicing in the court in which he works.

Other codes of conduct which a judge shall abide by is to abide to the legal boundaries when exercising the freedoms stipulated in the constitution. On the other hand, the judge shall not belong to political parties, blocs, political associations or participate in any of its activities ${ }^{14}$.

Based on the previous code of conduct, any violations to these obligations will lead to the violation of the rights of litigants. And whether the judge is acting positively by performing his duties properly or acting negatively, by failing to do his duties. In both cases, he must be adhered to these codes of conduct to preserve the dignity and prestige of his profession $^{15}$.

\subsubsection{Violations of the judge's personal life}

According to the code of judicial conduct, the judge or any of his dependent family members shall not accept or ask for a gift, reward or loan, that would otherwise not be obtained but for the judge's judicial status. And, he shall not behave in a manner that implies or creates an impression in others that one of his family members, or any other person has an influence on his judicial functions.

Another violation which a judge shall not commit is taking advantage of his position in order to promote his personal interests. These obligations may interfere in his personal life as he must limit non-official events or accept invitations that influence his behavior.

Moreover, he must consider his behavior even on the means of social communication, which affects the sanctity of his message and to refrain from receiving opponents or agents in his home to the extent that avoids the suspicion of prejudice or neutrality ${ }^{16}$.

Accordingly, we conclude that these obligations have not only imposed on the judge's work conditions, but also imposed on his personal life and it extended to impose restrictions on his family.However, such obligations may be justified because the judge's role is to guarantee the rights of individuals and to earn their confidence. If the judge violates the obligations that he must abide by, He will be subject to these sanctions:

\subsubsection{Disciplinary sanctions:}

A-Warning:

The penalty of warning means to draw the judge attention to an act he does and to inform him not to do it again in the future $^{17}$. It is one of the disciplinary punishments received under article (27) of the Judicial Independence Law that is ,the Chairman, of his own accord or upon a submission made by the court chief in charge to warn the judge in writing in respect of infractions made by the judge contradictory to his duties and position demands...)

\footnotetext{
13 Judiciary Independence law, op. Cit

14 Judicial Code of Conduct for the year 2017, site of the Jordanian Judicial Council, date of visit 11/4/2019

15 Ahmed Makhlouf, op. Cit., P. 407.

16 Articles 23, 24, Judicial Code of Conduct, op. Cit.

17 Kanaan, N (2012) Al-Wajeez in the Jordanian Administrative Decision, C2, I4, The Bright Prospects-2012, p. 164
} 


\section{B-Notice}

It is a written notice to the employee of the offense he committed to warn him against the breach of his future duties, which is provided for in the Judicial independence Law ${ }^{18}$.

The judge shall be subject to the penalty of withholding the annual increase for a period not exceeding one year if the judge commits an offense punishable by a warning or a notice ${ }^{19}$.

\section{C- Reduction in rank (Demotion)}

According to the judiciary Independence Law, Article (37) paragraph (c) ${ }^{20}$, it implies placing the employee at a lower rank than the one he occupies ${ }^{21}$.

\section{D- Termination of service}

Applying this penalty means to terminate the employment relationship between the employee and the state, which is considered one of the most severe penalties because of its impact on the status of the job and financial ${ }^{22}$.

E-Dismissal. (removal)

This penalty is one of the most severe penalties applied to an employee, as it terminates all employee services and deprives him of all his financial rights. The employee who has been dismissed cannot be appointed to any other public office ${ }^{23}$.

By studying the last penalty, dismissing, we can realize an important principle which is guaranteed by law that is the principle of irremovability of judges.

3.1.4 The Principle of non-removal of judges. This principle means that a judge may not be dismissed or suspended from work or referred to retirement before the legal time or transferred to a post other than judicial, except in circumstances stipulated by law ${ }^{24}$

But this does not mean that if the judge conducts unacceptable actions that are not commensurate with the requirements of his job, he remains in office and remains irremovable.

Article (25) paragraph (a) states that "It's not allowed to dismiss, terminate the service, or lower in rank of the judge but according to a decision of the Council and a High Royal Decree" 25 .

If the judge committed the offense, the penalty must be imposed on this violation. It is necessary to know the procedures in order to impose the penalty in addition to understand what guarantees and which are restrictions on these procedures.

\subsection{Procedures and guarantees of discipline}

The penalty shall not be imposed on the judge directly in the event of committing the offense, it is necessary to go through certain procedures until reaching the stage of determining the penalty, which is the last stage of the proceedings.

\subsubsection{Disciplinary procedures}

The Judicial Independence Act stated that the judge is referred to disciplinary action by a decision of the Judicial Council to institute a disciplinary action against him from the Attorney-Genera ${ }^{26}$. The referral of the judge to the Disciplinary Council is in the hands of the Judicial Council only. Once the Council approves, a disciplinary action is initiated by the Attorney-General to commence the proceedings.

The Judiciary Independence Law, Articles (32-35) provides for the disciplinary proceedings of judges before the Disciplinary council, as follows: The disciplinary action against the judge shall be instituted through a bill of indictment includes the charge or charges he is accused of and the evidence supporting the charge(s), and should be presented to the disciplinary council to take a decision to appear before it. The disciplinary council shall have to initiate the procedures within a period of fifteen days maximum from the date of presenting the bill of indictment. The disciplinary council has the right to conduct any investigations it deems necessary and to deputize one of its members to do so.

\footnotetext{
18 Article 37, paragraph (b), the judiciary Independence Law, op. Cit

19 Article 20, paragraph (b), the judiciary Independence Law, op. Cit

20 the Judicial Independence law, op. Cit

21 the Judicial Independence law, op. Cit

22 Kanaan, N op. Cit., P. 169.

23 Nazir al-Qaisi, op. Cit., P. 286

24 Article 27 the Judicial Independence law, op. Cit

25 Article 25, Judicial Independence law, op. Cit.

26 Article 27, Judicial Independence law, op. Cit
} 
The disciplinary council or its deputized member for investigations have the authority empowered to courts regarding summoning witnesses deemed necessary for testimonies hearing or to obtain any other evidence. And then after the council completes these investigations, if it finds that there is no seriousness in the complaint submitted and there is no reason to proceed in the case, it retains the file of the investigation. The judge may not be prosecuted for that complaint, so that if the complaint is not serious, then the judge cannot be held accountable even after his service ends. If the disciplinary council locates any significance to proceed the action for all or some charges, it shall call the judge to present to the trial provided that the period between the call and the trial date shouldn't be less than seven days. The summons must include an appropriate statement of facts and indictment evidence.

If the disciplinary council finds that the infraction which the judge referred to discipline is accused with involves a penal crime, then it has to discontinue all disciplinary procedures and relegate the judge, investigation report, papers and other documents related to the infraction to the competent prosecuting attorney or to the competent court to proceed the case according to the rules of law. In such a case, it's impermissible to take any disciplinary action against the judge or to proceed with any procedure taken against him till delivering an irrevocable verdict in the claim or the penal proceedings instituted against him.

However, clearing the judge from the claim or proceedings instituted against him or delivering a non-responsibility judgement do not deter from taking the appropriate disciplinary actions against him for the infraction he committed and imposing the adequate disciplinary penalty on him if pronounced guilty. This is because the penalties issued by the Disciplinary council are administrative rather than judicial.

The disciplinary proceedings shall be terminated in event of the judge's resignation and the approval of the Council of such a resignation, or transferring to retirement, where the disciplinary proceedings have no effect on the penal or civil proceedings risen from the same fact.These procedures granted guarantees to the judge. This is evidenced by the judgments of the former High Court of Justice and the judgments of the Administrative Court at present from a statement of these procedures and guarantees ${ }^{27}$.

\subsubsection{Disciplinary guarantees:}

To achieve the balance between the independences of the judge and the imposition of disciplinary penalties on him, there must be guarantees to ensure this balance and the most important of these guarantees are the following:

\subsubsection{The neutrality of the Disciplinary Council}

These are fundamental guarantees that must be available when investigating and prosecuting a judge, because the influence of disciplinary decisions, whether for the benefit of the judge or against him, affects trust in the judicial bodies.

The most important part of this guarantee is that the members of the investigation and accusation authority are different from the members of the Disciplinary Council. This is because the investigator, when carrying out the task and issuing the decision to refer the judge to the court and investigate with him, is returned before the judge again. The inspected judge opinion remains the same and he will try to defend his opinion. This will affect the independence of the judiciary $^{28}$.

However, the administrative court in one of its decisions went on to say that it is not its authority to determine the validity of the composition of the Disciplinary Council and this was after the appeal of the disciplinary decision issued by the appeal which based on the presence of three judges in the disciplinary council who had made the decision to refer the judge to the disciplinary council, The High Court of Justice went on to say that the Judicial Council is the one to adjudicate these matters and that it is not within its jurisdiction ${ }^{29}$.

\subsubsection{Conducting Investigation with the judge}

The judge shall not be disciplined once a complaint has been filed against him, or even referred to the Disciplinary Council. Rather, it must be ascertained that the judge has committed this offense through evidences. In addition, the judge must be notified of the charges attributed to him and the evidence of the offences he conducted to give him the opportunity to defend himself. He shall be aware of the surrounding matters. The Disciplinary Council of Judges is therefore obliged to investigate with the assigned judge, in addition to the fact that all such investigations and hearings must be confidential. ${ }^{30}$

\footnotetext{
27 Administrative Tribunal, See Decision No. 339 of 2015, issued on 10/2/2016, your decision

28 Kanaan, N, op. Cit., P. 192.

29 See Administrative Court, Decision No. 185 of 2014, 15/2/2015, Supreme Administrative Court, Decision No. 91 of 2015, dated 26/5/2015.

30 Article 32 (b), Judicial Independence law, op. Cit.
} 


\subsubsection{Writing the investigation}

In order for the disciplinary decision issued against the judge to be safe from the appeal, this investigation must be written in the sense that the writing is the strongest evidence through which the charges against the judge can be proved and the proportionality between the charge attributed to the judge and the punishment imposed on him ${ }^{31}$.

\subsubsection{Guarantee the right of defense}

Article (34), paragraph (b) states: "The judge has the right to present his defense in writing or orally, and he or the representative has the right to discuss witnesses heard by the Disciplinary Council during the preliminary investigations ${ }^{32}$.

It granted the judge the right to defend himself and did not require that his defense be in a form. He could defend himself by writing or orally, in addition to giving him the opportunity to defend himself or by assigning a lawyer to carry out defending. He may also be represented by another judge before the Disciplinary Council.

\subsubsection{Causation of decision}

Which is a statement of facts and its causes and the reasons for the imposition of a sanction.

Causation is considered the most important guarantees of the protection of the judge from the arbitrariness of the disciplinary council. Causation has granted the administrative judiciary control on the disciplinary council in how to adapt to the violation ${ }^{33}$.

Article (35) stipulated that "The delivered judgment in disciplinary proceedings should contain the reasons on which it was built on, and these reasons must be read at judgement delivery where such a judgement is appealable at the Supreme Court ${ }^{34}$."

This provision is considered an additional safeguard for the judge, namely, that decisions made by the Disciplinary Council shall not be considered not appealable.

After the statement of the disciplinary procedures and clarifying the guarantees surrounding these procedures, the disciplinary council shall issue the decision. In fact, the judge is a public official who subordinated to the Judicial and Disciplinary Council administratively, so the decision against the judge is an administrative decision.

4. The monitoring of the administrative judiciary on the disciplinary decisions of judges. Pursuant to Article (35), the judgment in the disciplinary case is subject to appeal to the Supreme Administrative Court ${ }^{35}$. The decision against the judge is therefore an administrative decision, which must include all the formality elements of the administrative decision.

Therefore, the administrative judiciary has the right to monitor the availability of these elements and it is stated that "Other than the cases indicated in this Law, judges are subject to Civil Service Bylaw and any other legislation related to employees". The Judicial Council shall exercise the power of the Council of Ministers ${ }^{36}$.

Article (5) (A / 4) stated that the Administrative Tribunal was competent to hear staff appeals concerning the annulment of final decisions against disciplinary authorities ${ }^{37}$.Therefore, the administrative judiciary's monitoring over disciplinary decisions will be dealt with through the administrative justice law.

The administrative decision is based on five elements namely jurisdiction, form, reason, legal status and purpose.

\subsection{The Monitoring of the formality elements of judges' disciplinary decisions.}

Administrative decision has two formal elements: the specialized element and form element.

\subsubsection{The element of Jurisdiction.}

Jurisdiction is defined as determining who is legally empowered to issue a decision that is legally valid. In accord to Judiciary Independence Law, the vested authority to issue disciplinary decisions is the Disciplinary Authority. ${ }^{38}$. The disciplinary decision is considered defect if it lacks subject-matter jurisdiction, that is if it was issued by a party other than the Disciplinary Council. This defect has many consequences, the most important of which is that the lack of jurisdiction is one of the matters related to public order.

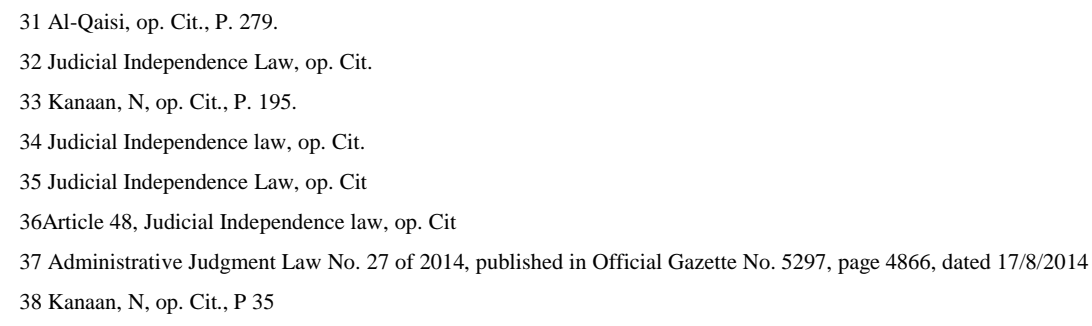


This means that it can be appealed against the decision at any stage of the lawsuit. Individuals cannot agree to this violation even if the judge approved the disciplinary decision issued by a non-competent authority. Consequently, this decision could not be considered a right decision ${ }^{39}$.

The lack of jurisdiction that is affected by the administrative decision comes in two forms: A defect in the absence of competence which is called by the jurisprudence, the usurpation of power, a decision issued by an individual who has no status that he does not have the status of public official, In this case the decision can be appealed against at any time. Or in the form of a defect of lack of simple jurisdiction, which is the decision issued by a public official, but does not have the competence to issue such a decision and result in the invalid of the decision and he is immune is against appealing (rejecting) after the expiration of the period specified by law ${ }^{40}$.

\subsection{2: The Element of Formality}

The disciplinary decision is in fact an administrative decision .

Thus, when the disciplinary council issues the decision, it is intended to express its will to make a legal effect. However, the law has sometimes stipulated that. This will must have a specific form because administrative decisions usually have no specific form for issuing an administrative decision ${ }^{41}$.

Al Fqih defined the formality defect by several definitions, including: Ignore the formal administration specified by the legal texts or regulations for the issuance of the administrative decision. Others have defined it as the lack of respect for the administrative rules of procedure and objectivity specified by the law for the issuance of administrative decision ${ }^{42}$.

Formality in the administrative decision is divided into formalities substantial and unsubstantial defects. In the substantial formalities, the formality defect is substantial when this formality is stated in the law and regulations. The absence of such formality in the administrative decision leads to the non-arrangement of the decision as having no legal effect. If the formality is unsubstantial, which is not provided by the legislator, in this case the administration can remedy such a defect and reform it ${ }^{43}$.

An example of a formality defect in a disciplinary decision is that. It does not cause disciplinary action, pursuant to article (35) of the Judiciary Independence Law, the decision should be made. Which is confirmed by the Supreme Court of Justice in its principles, as mentioned (since the investigation must be in written and it is not correct to rely on an oral investigation). Basically, the investigation is one of the basic rules relating to public order. It also relates to the right of the employee to record everything related to his charge so that this written investigation will be under the consideration of all responsible bodies that look forward to it) ${ }^{44}$.

4.2 Administrative monitoring over the substantive elements of disciplinary decisions. The availability of formality elements alone is not enough, considering that the decision is issued by the body authorized by law to issue it, and that it has the formality required by law, this in itself is not sufficient to consider the administrative decision as a valid decision, but there are other conditions related to the content of the decision.

\subsubsection{The element of legal status}

The element of status in the administrative decision is the legal effect that the administrative decision will take upon its issuance, namely the establishment, modification or cancellation of the legal status ${ }^{45}$.

The case of violation of the status in the disciplinary decisions, that is, the decision has the defect of status in the event of violation of the legal rules, whether the violation is direct by acting contrary to what was provided in the law in full or partial, such as the refusal of the administration to return the employee to work after the cancellation of the decision to dismiss, or the violation was indirect, namely in the interpretation or application of legal rules ${ }^{46}$.

For an example, the High Court of Justice rejected the plaintiff's case because the case had already been filed by the court and the court dismissed its subject matter. The prosecution then claimed that the new case had become closed and not subject to the loss of one of the conditions of acceptance that is status. ${ }^{47}$

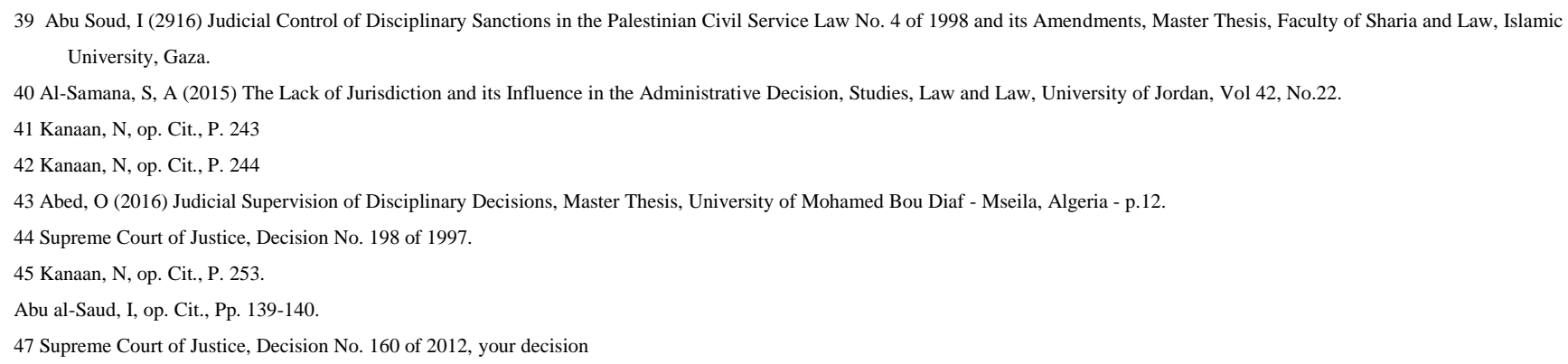




\subsubsection{The element of purpose}

It is the direct and final objective that the administration seeks to achieve when issuing the administrative decision 48 . The defect of the purpose in the administrative decision is referred to as the deviation of the use of power. This is the case if the administration uses the administrative decision to achieve certain purposes. Therefore, the defect of the purpose is two represented in two aspects, a deviation from the public interest or a violation of the rule of allocation of objectives 49

In the field of discipline, the purpose may be to limit the aim of the administration from imposing punishment on the employee to achieve a personal purpose away from the public interest.

It is considered one of the principles that the Supreme Court of Justice based on. When decisions are made by the administration, they are aimed at the public interest and those who claim otherwise to prove, the burden of proving that the authority deviated from the objective whether it is intended to bring a benefit or to achieve personal interest, The victim has to prove it $^{50}$.

\subsubsection{The element of reason}

Which is the legal or physical situation that precedes the issuance of the administrative decision, which is the reason for the issuance of the administration of this resolution ${ }^{51}$.The importance of explaining the reason for the administrative decision is the possibility of extending the judiciary control of the motives of the administration to issue such a decision.

There are types of supervision of the judiciary to the defect of causation, which is to control the physical presence of the facts, which confirms the administrative judge of the facts that called for the administration to issue this decision, and this by examining the previous and subsequent facts on the administrative decision, if there are no such facts the decision shall be considered defected and shall be cancelled.

The second type of supervision is the supervision of the legality of the administrative decision. The administrative judge shall ensure that all the characteristics required by law for the issuance of this decision are met ${ }^{52}$.

The causation of the disciplinary decision is deemed an important guarantee to ensure the fairness of the disciplinary sanction that is signed on the employee who violates the duties of his job, the purpose of whom is to protect him against the abuse of the authority of discipline ${ }^{53}$.

\section{Conclusions and Recommendations}

After studying the subject of disciplining judges, the most important conclusions and recommendations are.

\subsection{Conclusions}

1. When studying the subject of the inspection of judges we notice that Jordan tried hard to grant the judges full independence by trying to balance between the existence of the judicial inspection Council and between maintaining the independence of the judicial element through guaranteeing them during the inspection stage.

2. Jordan has made the judge subordinate the Judicial Council administratively. The purpose of this subordination is to regulate the Judicial body without any administrative or executive authority having any role in commenting on the judicial work.

3. Jordan was one of the first Arab countries to try to rid the judge of the hegemony of the executive authority and did not permit them to have any interference in the work of the judiciary.

4. The need for an independent judicial body called for the issuing laws, regulations and instructions that govern the discipline of judges and the precise task of those who carry out this task.

5. Despite this independence and the issuance of disciplinary decisions, but this did not prevent the possibility of the judge resorting to the judicial body to challenge the provisions that issued against him.

This shows the guarantees of the independence of the judge, the atheist judicial control of the judge's judgments.

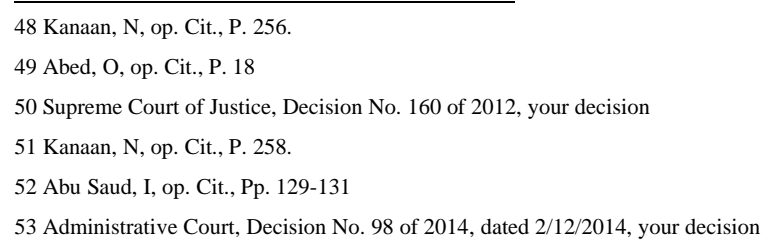




\subsection{Recommendations}

- To ensure the impartiality of the Disciplinary Council and not to influence it, it may be preferable not to disclose the names of the members of the Disciplinary Council, in an attempt to avoid the entry of mediation and ambiguity in the Council's decision.

- To establish a special system for how to challenge disciplinary decisions and not to be considered merely an administrative decision. So that the supervision of disciplinary decisions different from any other administrative decision.

\section{References}

\section{- Books:}

Al-Samana, S, A (2015) The Lack of Jurisdiction and its Influence in the Administrative Decision, Studies, Shari'a and Law University of Jordan, Vol 42, No.22.

Al-Qaisi, N, T (2017) The effect of the general disciplinary guarantees of judges in promoting the principle of judicial independence, studies, law and regulations, University of Jordan, Vol.44.

Kanaan, N (2012) Al-Wajeez in the Jordanian Administrative Decision, C2, I4, The Bright Prospects.

Makhlouf, A, S (2013) Waseet in explaining the new judicial organization in Saudi Arabia, Research Center.

Abu Sunh, M, H (2010) Judicial Inspection (Comparative Study), Journal of AL hakam, Volume 2010-2017, Issue 2010, Sudan.

\section{- University Thesis:}

Abed, O (2016) Judicial Supervision of Disciplinary Decisions, Master Thesis, University of Mohamed Bou DiafMseila, Algeria.

Abu Saud, I, I (2016) Judicial Control of Disciplinary Sanctions in the Palestinian Service Law No. (4) of 1998 and its amendments, Master Thesis, Faculty of Sharia and Law, Islamic University, Gaza.

\section{- Laws, regulations and instructions:}

The Judicial Independence Law No. (29) of 2014

Judicial Independence Law Amended No. (26) of 2017

Judicial Inspection System of the Regular Courts No. 100 of 2017.

Civil Service Law No. 82 of 2013 and its amendments

Instructions for inspection of the regular courts for the year 2018

Judicial Code of Conduct for the year 2017.

\section{Judicial decisions:}

Administrative Tribunal, Decision 2015, 2015.

Administrative Tribunal, Decision No. 185 of 2014.

Supreme Court of Justice, Decision No. 98 of 2014.

Supreme Court of Justice, Decision No. 378 of 2013.

Supreme Court of Justice, Decision No. 160 of 2012.

Supreme Court of Justice, Decision No. 198 of 1997.

\section{Websites:}

Ben Mehrez's codes of law and justice, judges' guarantees, are available on the legal website. 